\title{
Materials science aspects of zinc-air batteries: a review
}

\author{
Vincenzo Caramia $\cdot$ Benedetto Bozzini
}

Received: 2 January 2014/Accepted: 11 March 2014/Published online: 3 April 2014

(C) The Author(s) 2014. This article is published with open access at Springerlink.com

\begin{abstract}
Metal-air batteries are becoming of particular interest, from both fundamental and industrial viewpoints, for their high specific energy density compared to other energy storage devices, in particular the Li-ion systems. Among metal-air batteries, the zinc-air option represents a safe, environmentally friendly and potentially cheap and simple way to store and deliver electrical energy for both portable and stationary devices as well as for electric vehicles. Zinc-air batteries can be classified into primary (including also the mechanically rechargeable), electrically rechargeable (secondary), and fuel cells. Research on primary zinc-air batteries is well consolidated since many years. On the contrary, research on the electrically rechargeable ones still requires further efforts to overcome materials science and electrochemical issues related to charge and discharge processes. In addition, zinc-air fuel cells are also of great potential interest for smart grid energy storage and production. This review aims to report on the latest progresses and state-of-the-art of primary, secondary and mechanically rechargeable zinc-air batteries, and zinc-air fuel cells. In particular, this review focuses on the critical aspects of materials science, engineering, electrochemistry and mathematical modeling related to all zinc-air systems.
\end{abstract}

Keywords Zinc air batteries - Primary batteries . Secondary batteries $\cdot$ Fuel cells $\cdot$ Zinc $\cdot$ Air cathode

V. Caramia $\cdot$ B. Bozzini $(\bowtie)$

Dipartimento di Ingegneria dell'Innovazione, Università del

Salento, via Monteroni, 73100 Lecce, Italy

e-mail: benedetto.bozzini@unisalento.it

\section{Introduction}

In the modern industrialized society, the electrical energy demand is increasing exponentially [1]; but environmental pollution, due to the usage of fossil fuels for power generation, is a very well known and urgent problem $[1,2]$. Renewable and sustainable energy, such as solar and wind [3-6], could replace hydrocarbons, but it is also important to find a safe, reliable and efficient way to store such energy and use it in transportation systems and large-scale applications, for instance. For this reason, researchers and industry are looking for new strategies for better electrical energy storage devices. Among these, the batteries represent the right key for the next generation of green vehicles and grid energy storage, due to their relatively high energy density compared to supercapacitors that have, instead, a higher power density [7-9].

Nowadays, the need for energy storage in a robust and reliable electric grid is increasing as a result of the growing and worldwide use of renewable power generation [10]. In Japan, for instance, due to the potential decommissioning of nuclear fleet, it is becoming crucial the use of alternative and smart ways to generate, store and distribute electric energy [10]. Italy, instead, has substantial renewable capacity relative to grid size, and the grid is currently struggling with reliability issues; moreover, in the USA, Canada and Germany there is a keen interest to invest much more in renewable power sources (wind, solar, thermal, etc.,) [10-13]. For these reasons, it is important to develop more efficient grid storage systems. The currently available mature and reliable technologies for high system power ratings (100 MW-1 GW) are pumped hydro-storage (PHS) and compressed air energy storage. However, for smaller and smarter grids, electrochemical devices, chiefly batteries, play an important role for power rating in the 
Fig. 1 Batteries for electric drive vehicles. Reproduced with permission from [34]

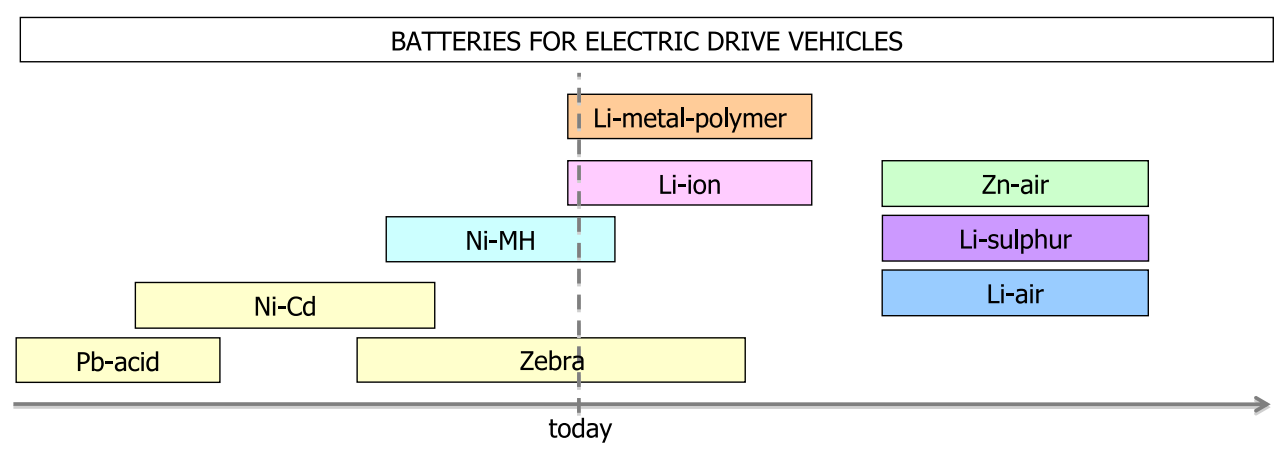

range from c.a. $1 \mathrm{~kW}$ to $10 \mathrm{MW}$ [9]. Among batteries, the following are the most investigated ones: the well known and widely used lead-acid ones, that have also recently undergone notable technical improvements; the more recent lithium ion-based technology concept; the redoxflow batteries (e.g., $\mathrm{Zn} / \mathrm{Br} ; \mathrm{Zn} / \mathrm{Cl}$, Vanadium-redox), and finally the sodium-sulfur and metal-air devices that are being actively studied by several industrial and academic institutions [14-19]. In this framework, metal-air batteries potentially represent the method of choice for smart and green grid storage, since their peculiarity is the high theoretical energy density and the low environmental impact of their components [12, 20]. Recently (2012), the EOS Energy company began its mission to employ zinc-air batteries for grid storage, believing in their potentialities over other types of batteries where less safe, scarce and expensive materials, such as lithium, are employed [21].

Even if the technology of lithium ion batteries (LIBs) is well established for portable applications such as mobile telephones, digital cameras, etc., their energy density is still not entirely satisfactory for electric vehicles (EVs) applications and driving ranges comparable to those typically obtained with fossil fuels. Nevertheless, electric vehicles totally based on Li-ion technology are commercially available with a full charge autonomy up to c.a. $200 \mathrm{~km}$, such as: Renault ZEO and Kangoo [22], BMW 1 series ActiveE [23], Ford Focus Electric [24], Mercedes Benz Smart Electric Drive [25], Mitsubishi Innovative Electric Vehicle ("I-MiEV") [26], Nissan Leaf [27], Tesla Model S [28], Toyota RAV4 EV [29], and Volkswagen e-up [30]. Furthermore, some automobile companies are selling vehicles with a hybrid technology; Toyota hybrid system has been in the market since 1997 using Ni-MH batteries, and since 2011 using Li-ion technology. Apart from Toyota, also Opel (Opel Ampera) [31], Ford [32] and Volkswagen [30] are in the market of hybrid electric vehicles powered by a Li-ion technology and by an internal combustion engine.

Therefore, in the near future, the so-called metal-air batteries could replace the ion-based technology as shown in Fig. 1 [33, 34]. Among all the different types of metal- air batteries-such as those based on $\mathrm{Ca}, \mathrm{Mg}, \mathrm{Li}, \mathrm{Zn}, \mathrm{Al}, \mathrm{Fe}$ and $\mathrm{Cd}-, \mathrm{Li}$-air and $\mathrm{Zn}$-air batteries are the most promising ones. A comparison between theoretical and practical gravimetric energy density ( $\mathrm{Wh} / \mathrm{kg}$ ) for different electrochemical energy storage devices is reported in Fig. 2 [35]. In detail, the practical energy density of lead-acid and $\mathrm{Ni}-$ $\mathrm{Cd}$ batteries is c.a. $40 \mathrm{Wh} / \mathrm{kg}$; that of $\mathrm{Ni}-\mathrm{MH}$ systems is $50 \mathrm{Wh} / \mathrm{kg}$, that of devices based on Li-ion chemistry is $160 \mathrm{Wh} / \mathrm{kg}$ and that of $\mathrm{Li}-\mathrm{S}$ concepts is about $370 \mathrm{Wh} / \mathrm{kg}$. The practical energy density of metal-air systems, instead, can be summarized as follows: $\mathrm{Zn}$-air $350 \mathrm{Wh} / \mathrm{kg}$, Al-air (not shown in Fig. 2) 1,300 Wh/kg and Li-air 1,700 Wh/ $\mathrm{kg}$ [36]. A very recent review on metal-air batteries, including the zinc-air ones, provides the reader with a general overview and comparison on the different metalair technologies [37]. To the best of our knowledge, a rich and recent scientific literature is available for $\mathrm{Li}$-air cells, but not for Zn-air systems. Nevertheless, apart from some debates on the last two technologies, which are summarized in the quite recent review of Lee et al. [38], from a materials science point of view it is very challenging to obtain an efficient electrically rechargeable metal-air battery employable for EVs.

Zinc as a metal is safer than lithium and can be fully recycled [39]. The availability of zinc is not a major problem, compared to lithium, since the number of zinc reserves is high around the world, currently the largest producers being China, Australia, Canada and the USA $[39,40]$. Some properties of the electrochemical zinc-air cells and other metals are listed in the Table 1 [41], where it is possible to notice that $\mathrm{Li}, \mathrm{Ca}, \mathrm{Mg}$ and $\mathrm{Al}$ have the highest specific energy, but they have very negative electrode potentials and, as a result, these electrodes corrode easily in aqueous electrolytes with the production of hydrogen gas.

A zinc-air battery, as schematically illustrated in Fig. 3, is composed of three main components: a zinc anode, an alkaline $(\mathrm{KOH})$ electrolyte and an air cathode (usually a porous and carbonaceous material). Oxygen diffuses through the porous air cathode, and the catalyst layer on the cathode allows the reduction of oxygen to hydroxide ions 


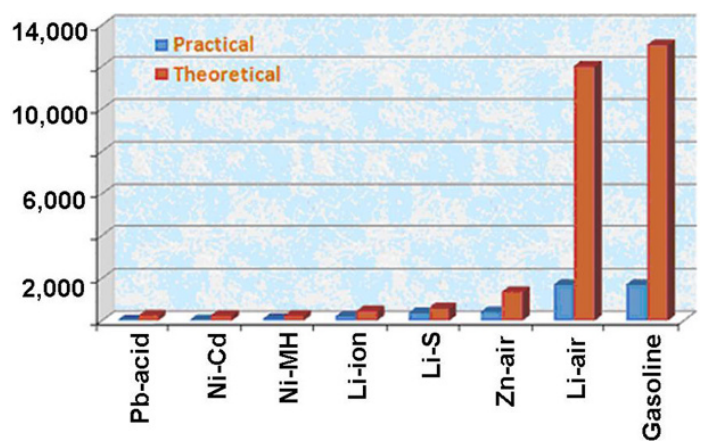

Fig. 2 Comparison of practical and theoretical gravimetric energy density $(\mathrm{Wh} / \mathrm{kg})$ for different batteries. Reproduced with permission from [35]

in the alkaline electrolyte with the electrons obtained from the electrochemical oxidation of the zinc anode. On recharge, oxygen will be evolved and diffuses out of the positive electrode, whereas zinc is deposited at the negative electrode. An oxygen electrode with dual catalytic activity (for ORR and OER) (not shown in Fig. 3) must be used for a rechargeable battery. This is a very hot topic and some key advancements have been recently published [42].

Zinc-air batteries can be classified into primary and electrically rechargeable. The former ones are commonly employed in hearing aid devices since the 1960s and represent a very well established technology without the need of further developments in terms of research on new materials and engineering improvements. The latter ones, on the contrary, still require research efforts to improve the efficiency and minimize obnoxious side effects occurring during the charging process [42], such as, for instance, zinc dendrites formation, limited number of charge-discharge cycles due to deterioration of the air cathode and carbonation of $\mathrm{KOH}$ electrolyte. In addition, in an electrically rechargeable zinc-air system, it is also important to deeply study and understand the chemistry of zincate solubility in the alkaline electrolyte as well as to develop new catalyst materials [42].

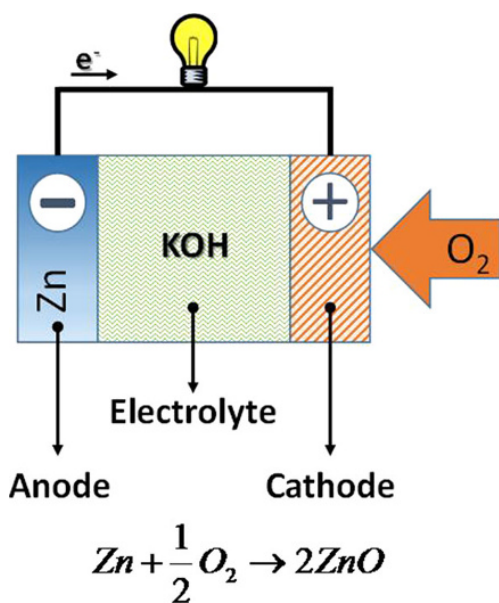

Fig. 3 Schematic illustration of a primary, not electrically rechargeable, zinc-air battery

This review provides a comprehensive summary of the latest developments in zinc-air battery and fuel cell science and technology, covering, in particular, the materials used for the anode, the cathode, and the electrolyte as well as all the problems currently limiting the widespread success of electrically rechargeable zinc-air batteries.

\section{Primary zinc-air batteries}

This section concentrates on anodic, electrolytic and cathodic materials employed in primary zinc-air battery. From the point of view of applications, primary $\mathrm{Zn}$-air batteries are well known for use in hearing aid devices (button-type cells), as hinted at in the introduction. Nevertheless, large primary $\mathrm{Zn}$-air batteries have been also used to provide low rate and long-life power for applications such as seismic telemetry, railroad signaling and navigational buoys as well as remote communications. The theoretical specific energy density of $\mathrm{Zn}$-air batteries is $1,084 \mathrm{Wh} / \mathrm{kg}$. The theoretical voltage of a zinc-air cell is

Table 1 Characteristics of metal-air cells

\begin{tabular}{llllll}
\hline $\begin{array}{l}\text { Metal } \\
\text { anode }\end{array}$ & $\begin{array}{l}\text { Electrochemical equivalent of } \\
\text { metal }(\mathrm{Ah} / \mathrm{g})\end{array}$ & $\begin{array}{l}\text { Theoretical cell } \\
\text { voltage }^{\mathrm{a}}(\mathrm{V})\end{array}$ & $\begin{array}{l}\text { Valence } \\
\text { charge }\end{array}$ & $\begin{array}{l}\text { Theoretical specific energy } \\
\text { (of metal) }(\mathrm{kWh} / \mathrm{kg})\end{array}$ & $\begin{array}{l}\text { Practical operating } \\
\text { voltage }(\mathrm{V})\end{array}$ \\
\hline $\mathrm{Li}$ & 3.86 & 3.4 & 1 & 13.0 & 2.4 \\
$\mathrm{Ca}$ & 1.34 & 3.4 & 2 & 4.6 & 2.0 \\
$\mathrm{Mg}$ & 2.20 & 3.1 & 2 & 6.8 & $1.2-1.4$ \\
$\mathrm{Al}$ & 2.98 & 2.7 & 3 & 8.1 & $1.1-1.4$ \\
$\mathrm{Zn}$ & 0.82 & 1.6 & 2 & 1.3 & $1.0-1.2$ \\
$\mathrm{Fe}$ & 0.96 & 1.3 & 2 & 1.2 & 1.0 \\
\hline
\end{tabular}

Data derived from [41]

a Cell voltage with oxygen cathode 
$1.667 \mathrm{~V}$, but, in practice, the open circuit voltage is about $1.35 \mathrm{~V}$. In addition, the discharge curve of a $\mathrm{Zn}$-air cell is flat with minimum potential decay-compared to Li-air systems-when a constant current density $\left(50-100 \mathrm{~mA} \mathrm{~cm}^{-2}\right)$ is applied at the battery, and the voltage is measured and monitored over discharge time.

Anode materials

The anode materials of any $\mathrm{Zn}$-air battery is simply zinc, employed in different forms such as powder or fibers, to increase efficiency. During discharge of the battery, the following chemical reaction scheme describes the processes involved at the zinc anode in alkaline solutions:

$\mathrm{Zn} \rightarrow \mathrm{Zn}^{2+}+2 \mathrm{e}^{-}$

$\mathrm{Zn}^{2+}+4 \mathrm{OH}^{-} \rightarrow \mathrm{Zn}(\mathrm{OH})_{4}^{2-}$

$\mathrm{Zn}(\mathrm{OH})_{4}^{2-} \rightarrow \mathrm{ZnO}+\mathrm{H}_{2} \mathrm{O}+2 \mathrm{OH}^{-}$

$\mathrm{Zn}+2 \mathrm{H}_{2} \mathrm{O} \rightarrow \mathrm{Zn}(\mathrm{OH})_{2}+\mathrm{H}_{2} \uparrow$

In particular, during discharge, the oxidation of the zinc electrode can involve several processes including oxidation of surface zinc atoms, ion solvation in the solution, ion diffusion in the electrolyte and precipitation into a solid phase when the solubility limit is reached.

Some interesting properties of zinc relevant to battery applications (at room temperature) are listed in the Table 2 [43]. One of the most important characteristics of $\mathrm{Zn}$ metal is its low electrical resistivity, equal to $5.96 \mu \Omega \mathrm{cm}$. In addition, the corrosion rate of zinc in alkaline solutions is not very fast compared, for instance, to aluminum; but during the anodic discharge of the battery, as it is possible to conclude from reaction (4), the hydrogen evolution (HER) in the form of gas is problematic. In particular, due to the basicity of the concentrated (4-9 M, with $\mathrm{pH} \sim 14$ in order to ensure a high ionic conductivity) $\mathrm{KOH}$ electrolyte in aqueous solutions-usually employed in $\mathrm{Zn}$-air batteries-, zinc corrodes producing hydrogen, as summarized in the Pourbaix diagram (Fig. 4a) [44], giving rise to charge losses and potentially dangerous hydrogen gas buildup. It is
Table 2 Properties of zinc relevant to battery applications (at room temperature)

\begin{tabular}{ll}
\hline Atomic weight & 65.38 \\
Crystalline structure & $\begin{array}{l}\text { Closed packed } \\
\text { hexagonal }\end{array}$ \\
Density & $7.14 \mathrm{~g} / \mathrm{cm} 3$ \\
Melting temperature & $419.5^{\circ} \mathrm{C}$ \\
Resistivity & $5.96 \mu \Omega \mathrm{cm}$ \\
Ion valence & 2 \\
Ionic radius & $0.074-0.083 \mathrm{~nm}$ \\
Stable dissolved form in $\mathrm{KOH}$ & $\mathrm{Zn}(\mathrm{OH})_{4}^{2-}$ \\
Standard potential & $-0.763 \mathrm{~V}_{\mathrm{SHE}}$ \\
Reversible potential in $35 \% \mathrm{KOH}$, & $-1.35 \mathrm{~V}_{\mathrm{SHE}}$ \\
8.2 mol/L &
\end{tabular}

Adapted from [43]

SHE standard hydrogen electrode

also worth noticing that, when the $\mathrm{pH}$ is lower than 13 , passivation of zinc results in the formation of stable (known as type II), compact, insoluble and n-type semiconductor zinc oxide $(\mathrm{ZnO})$, that is inconvenient for battery operation [45].

The rest of this section will be devoted to the discussion of the different types and configurations of $\mathrm{Zn}$ anodes for primary $\mathrm{Zn}$-air batteries. The use of zinc foil is inconvenient, because it reduces the performance of the electrochemical cell due to the low surface area. In order to increase the surface of the zinc anode particular strategies can be adopted, resulting in an enhancement of the battery lifecycle; among these solutions, the use of nano- and microstructured materials plays an important role. Figure 5 shows the different forms of zinc materials that have been employed as anodes in both primary and secondary zincair batteries [43, 46, 47]. All these types of zinc materials have different values of porosity. A suitable value of porosity is crucial to discharge the battery at large current densities with minimal voltage losses and long durability. A porosity value in the range between 60 and $80 \%$ is commonly found at the anode of a $\mathrm{Zn}$-air battery, which corresponds to a capacity of $1.2-2.2 \mathrm{Ah} / \mathrm{cm}^{3}$. Moreover, it is worth noticing that, as reported in Fig. 6 [47], the
Fig. 4 a Pourbaix diagram of zinc [44]; $\mathbf{b}$ fractions of different $\mathrm{Zn}^{2+}$ species formed as a function of $\mathrm{pH}$ for a zincwater system. Reproduced with permission from [45]
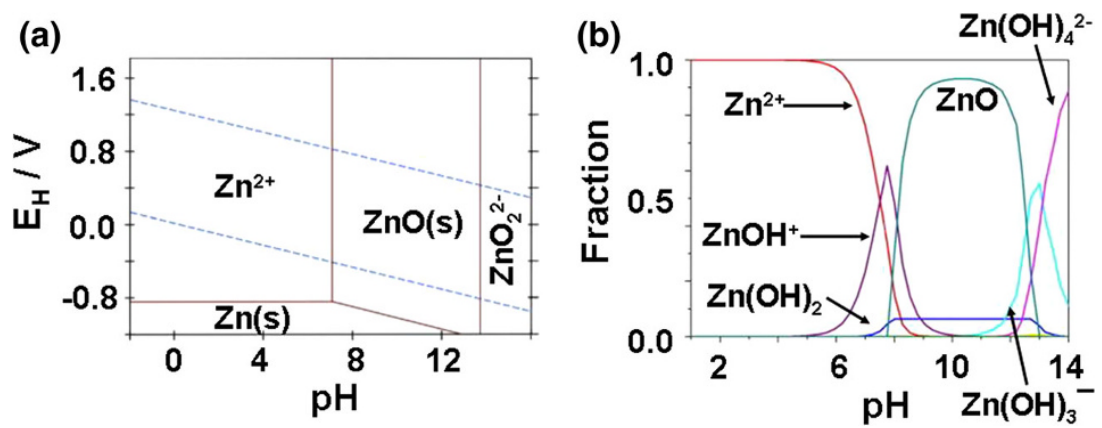


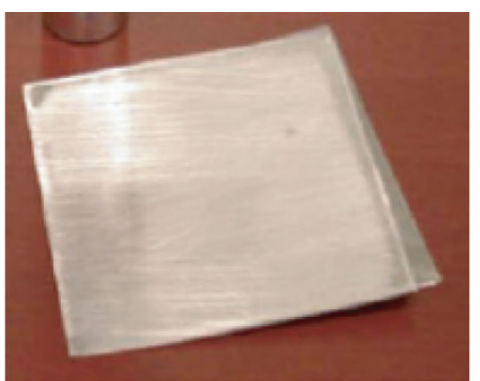

Rolled sheet

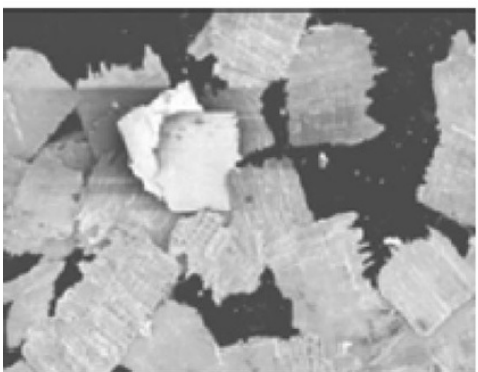

Cast ribbon

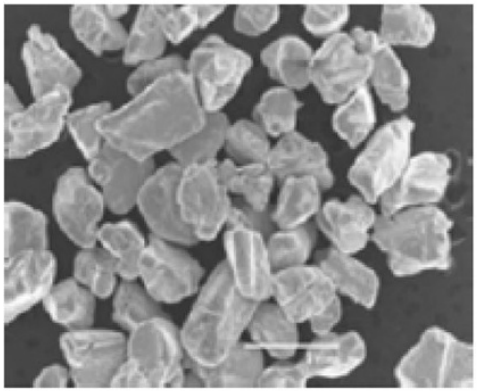

Cast/chopped pellets

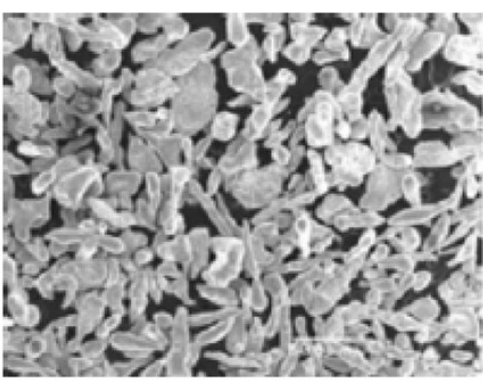

Atomized powder

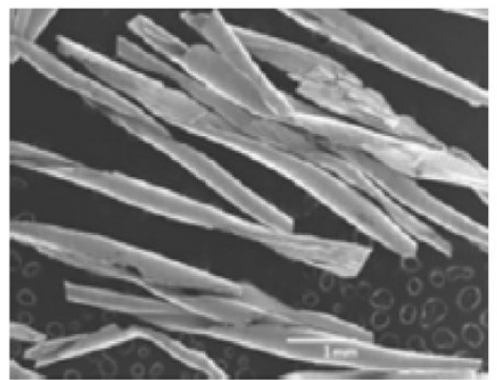

Machined threads

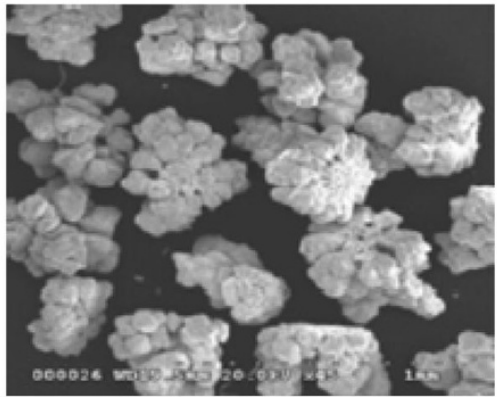

Electrodeposited pellets

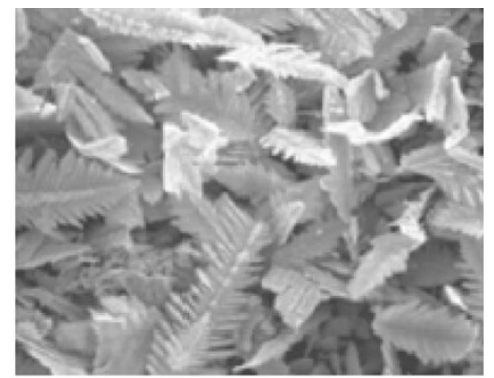

Dendritic powder

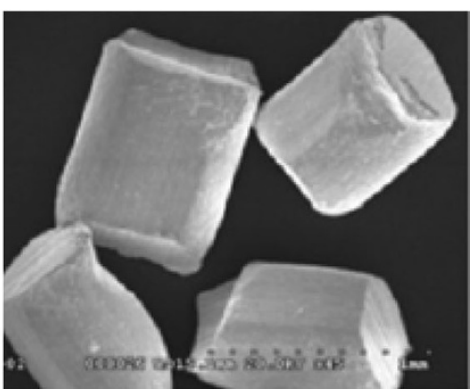

Cut wire pellets

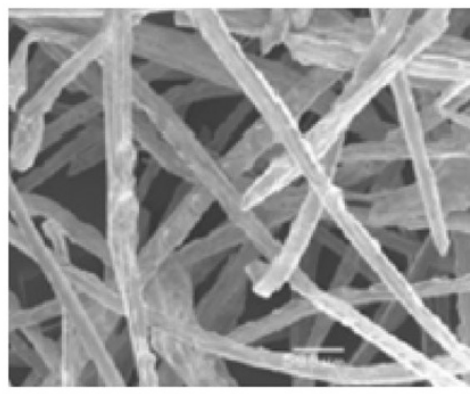

Cash fibers

Fig. 5 Different forms of zinc materials produced by different methods. Reproduced with permission from [43]

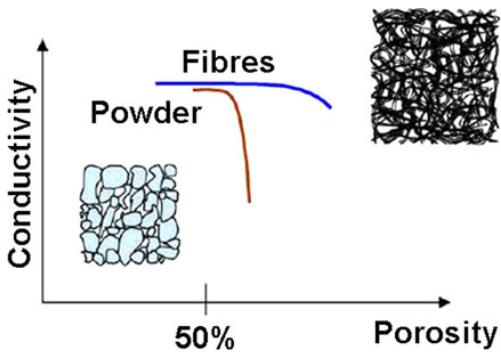

Fig. 6 Qualitative relationship between conductivity and porosity for powder electrodes and fibrous electrodes. Reproduced with permission from [47]

conductivity of the zinc anode behaves in different ways, depending on the morphology of the material (powder or fiber) and on its porosity. Fibrous zinc has a better electrical performance in the range of porosities required for an efficient $\mathrm{Zn}$-air battery. On the contrary, an atomized zinc powder has a low porosity (about $50 \%$ ), and, for this reason, a gelling agent is used to make a mix of zinc powder and electrolyte, such that the former is suspended in the electrolyte gel and, then, increases the porosity of the anode material to c.a. $70 \%$ [48, 49]. Different types of gels or binders have been reported, such as polytetrafluoroethylene (PTFE) [50, 51], sago [49, 52], carbopol gel [53], and a tapioca binder [54]. Notwithstanding its advantages in terms of porosity enhancement, the use of gelling agents increases both electrolyte resistance and manufacturing costs.

It is important to note that, when the zinc anode is employed in dispersed forms such as powder or fiber, mercury is typically added to enhance the electrical conductivity and to reduce the evolution of $\mathrm{H}_{2}$ [55]. Of course, mercury ought to be replaced in sustainable $\mathrm{Zn}$-air technologies. Four chief strategies have been developed for $\mathrm{Hg}$ replacement, mainly aiming to increase the overpotential for hydrogen evolution.

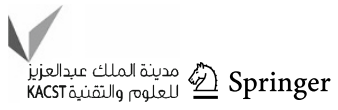


(i) Alloying zinc with other metals $(\mathrm{Pb}, \mathrm{Cd}, \mathrm{Ni})$ with high hydrogen evolution overvoltage (a potentiodynamic polarization analysis is used to measure the relevant overpotential). However, all these elements are either highly toxic or not environmental friendly. For this reason, Zhang et al. [56] suggested the introduction of metallic bismuth to a pasted zinc electrode. In addition, alloys of $\mathrm{Zn}$ and $\mathrm{Al}$ are also used not only to inhibit corrosion of $\mathrm{Zn}$, but also to increase the capacity of the anode material and decrease its weight [57] by harvesting both the reactivity of $\mathrm{Al}$ in alkaline solutions and its density. Special attention has been devoted to the more environmentally acceptable $\mathrm{Zn}-$ $\mathrm{Ni}$ alloy system. The comparative corrosion of $\mathrm{Zn}$ and $\mathrm{Zn}-\mathrm{Ni}$ alloys in different conditions (temperature and concentration of the $\mathrm{KOH}$ electrolyte) has been studied in [58] by potentiodynamic and impedance methods. By plotting the corrosion current vs. concentration of $\mathrm{KOH}$ electrolyte $(\log [\mathrm{KOH}])$ for $\mathrm{Zn}$ and $\mathrm{Zn}-\mathrm{Ni}$ alloys, a linear trend is observed for each alloy. Of course, by alloying $\mathrm{Zn}$ with $\mathrm{Ni}$, the corrosion resistance of the pure metal is enhanced.

(ii) Addition of $\mathrm{Al}_{2} \mathrm{O}_{3}$ either by mixing of $\mathrm{Zn}$ and $\mathrm{Al}_{2} \mathrm{O}_{3}$ particles or by surface modification of the $\mathrm{Zn}$ powders with an $\mathrm{Al}_{2} \mathrm{O}_{3}$ coating, deposited via a chemical solution process (see also Fig. 7 for details on the respective effects) [59]. The effectiveness of the approach was tested by comparing the volumetric amount of hydrogen spontaneously evolved on the surface of bare $\mathrm{Zn}, \mathrm{Al}_{2} \mathrm{O}_{3}$ mixed with $\mathrm{Zn}$, and $\mathrm{Zn}$ powders coated with $\mathrm{Al}_{2} \mathrm{O}_{3}$ in a $9 \mathrm{M} \mathrm{KOH}$ electrolyte at $60{ }^{\circ} \mathrm{C}$. The hydrogen evolution is almost suppressed in the presence of the alumina coating, owing to the formation of a passivation layer that prevents direct contact of $\mathrm{Zn}$ with the $\mathrm{KOH}$ electrolyte.

(iii) Coating the zinc metal particles with other materials such as $\mathrm{Li}_{2} \mathrm{O}-2 \mathrm{~B}_{2} \mathrm{O}_{3}$ in a core-shell structure. This configuration prevents the zinc particles from contacting directly the alkaline electrolyte, thus hindering corrosion side-reactions.

(iv) Mixing the alkaline electrolyte with organic corrosion inhibitors such as (a) anions of organic acids [60], (b) $\mathrm{HCO}_{2}-\mathrm{CH}_{2}-\left(\mathrm{OCH}_{2} \mathrm{CH}_{2}\right)-\mathrm{CH}_{2}-\mathrm{CO}_{2} \mathrm{H}$ dicarboxylic acid-modified poly(ethylene glycol) [61] and phosphoric acid esters (e.g., GAFAC RA600) [62].

\section{Cathode materials}

The cathode is, of course, an "air cathode" and performs the reduction of $\mathrm{O}_{2}$ to complete the redox reaction of the battery. Being a gas electrode, the cathode has to be porous

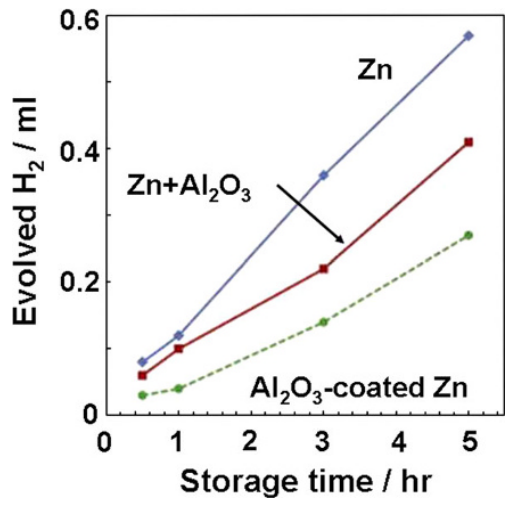

Fig. 7 Comparison of volumetric amount of hydrogen spontaneously evolved on the surface of bare $\mathrm{Zn}, \mathrm{Al}_{2} \mathrm{O}_{3}$ mixed with $\mathrm{Zn}$, and $\mathrm{Al}_{2} \mathrm{O}_{3}$ coated $\mathrm{Zn}$ gel anodes in a $9 \mathrm{M} \mathrm{KOH}$ electrolyte at $60{ }^{\circ} \mathrm{C}$. Reproduced with permission from [59]

and electrocatalytically active. The cathodic electrochemical reaction can be written as follows:

$\mathrm{O}_{2}+2 \mathrm{H}_{2} \mathrm{O}+4 \mathrm{e}^{-} \rightarrow 4 \mathrm{OH}^{-}$

Since an alkaline solution is typically employed in $\mathrm{Zn}-$ air batteries, Eq. (5) represents the typically favored mechanism [63, 64]. As far as the catalysts are concerned, $\mathrm{Zn}$-air batteries do not require precious metal catalysts, such as platinum, ruthenium or palladium, for the relevant chemistry; moreover, it has also been shown that noble catalysts tend to decrease the electrochemical performance since noble metal traces, released from the cathode, tend to diffuse to the zinc anode, lower its hydrogen overvoltage thus enhancing corrosion and gas production. References [33, 65] review the electrochemistry of the oxygen reduction reaction in metal-air batteries (including Zn-air ones) as well as the relevant catalysts. Moreover, Ref. [66] comprehensively compiles the published catalyst options and cathode configurations, with special attention to the patent literature. Among air cathode materials, $\mathrm{Fe}$ - and $\mathrm{Co}-$ based catalysts obtained by pyrolysis of $\mathrm{N}$ - and C-containing precursors (such as polypyrrole and polyaniline) [67] as well as graphene loaded with $\mathrm{Mn}_{3} \mathrm{O}_{4}$ nanoparticles [68] and CNT mixed with $\mathrm{CoO}$ [69], have been shown to be efficient for primary $\mathrm{Zn}$-air batteries and to exhibit better performance than noble metals. The role of the carbonaceous materials is to support the catalyst and to create a porous and electronically conductive path. However, to avoid leakage of the electrolyte from the air cathode (see, e.g., [70]), superhydrophobic materials, such as polytetrafluoroethylene (PTFE), are also employed as fillers in the fabrication of air cathodes [64].

References [71-90] provide a comprehensive description of the available air cathode fabrication concepts that can be summarized as follows: (i) Teflon ${ }^{\circledR}$ membrane on 
the air side with a high air permeability of $2,000-4,000 \mathrm{~s}$ (Gurley method). This membrane protects the air cathode against possible leakage of electrolyte to the current collector. (ii) Current collector, typically a Ni mesh, a cheaper woven copper mesh with $\mathrm{Ni}$ coating, or an expensive $\mathrm{Ni}$ foam. Ni foam has been reported to exhibit a typically higher surface area, ensuring a better performance of the air cathode. (iii) Gas diffusion layer (GDL) chiefly composed of acetylene blacks (AB) with low BrunauerEmmett-Teller (BET) surface area and wettability mixed with polytetrafluoroethylene (PTFE). The use of acetylene blacks with higher hydrophobic properties promotes more hydrophobic GDL properties. (iv) Catalyst layer: composed by the catalyst mixed with carbon blacks exhibiting high BET surface area and PTFE for hydrophobization.

\section{Electrolyte}

The most suitable electrolyte for $\mathrm{Zn}$-air batteries is potassium hydroxide $(\mathrm{KOH}$, some relevant properties of this electrolyte have been listed in Table 3), owing to its high ionic conductivity and low cost. Other electrolytes have been considered, chiefly $\mathrm{NaOH}$, but these have proved less effective. The concentration of $\mathrm{KOH}$ is selected in view of minimizing $\mathrm{Zn}$ corrosion and $\mathrm{H}_{2}$ evolution. $30 \%$ $\mathrm{KOH}$ is a typical compromise among good ionic conductivity, maximum solubility of zinc oxide and minimal zinc corrosion. One of the main problems with these aqueous alkaline electrolytes is carbonation, resulting from the presence of carbon dioxide in the atmospheric air. Not only does the formation of potassium carbonate lower the I-V curves and adversely affect the capacity of $\mathrm{Zn}$-air batteries, but-since potassium carbonate is less soluble than potassium hydroxide-it also causes pore clogging of air cathodes [70].

\section{Mechanically rechargeable $\mathrm{Zn}$-air batteries}

Among primary $\mathrm{Zn}$-air batteries, the mechanically rechargeable ones, schematically illustrated in Fig. 8, consist of a replaceable anode cassette comprising a slurry of zinc particles in contact with a potassium hydroxide solution and brought in contact-typically by gravitywith a current collector. The anode cassette is confined by a separator envelope and put into contact with the air electrode via a free-electrolyte compartment. Of course, the mechanical recharging policy allows fast regeneration of a spent cell in a configuration that preserves the benefits of a primary cell concept, but allows the body of the cell to be hosted in a more rugged way to the device exploiting the battery, in a way that is typical of secondary batteries. Of course, mechanically rechargeable batteries do not exhibit
Table 3 Properties of $\mathrm{KOH}$ electrolyte relevant to battery applications (at room temperature)

\begin{tabular}{|c|c|}
\hline Density of $35 \% \mathrm{KOH}, 8.2 \mathrm{~mol} / \mathrm{L}$ & $1.34 \mathrm{~g} / \mathrm{cm}^{3}$ \\
\hline Resistivity of $8 \mathrm{~mol} / \mathrm{L} \mathrm{KOH}$ & $2.3 \Omega \mathrm{cm}$ \\
\hline Solubility of $\mathrm{ZnO}$ in $35 \% \mathrm{KOH}, 8.2 \mathrm{~mol} / \mathrm{L}$ & $1 \mathrm{M}$ \\
\hline f rincate & $\begin{array}{l}2-4 \text { times of } \\
\text { solubility }\end{array}$ \\
\hline $\begin{array}{l}\text { Ratio of diffusion coefficient of } \mathrm{Zn}(\mathrm{OH})_{4}^{2-} / \\
\mathrm{OH}^{-}\end{array}$ & c.a. 0.1 \\
\hline Ratio of diffusion coefficient of $\mathrm{Zn}(\mathrm{OH})_{4}^{2-} / \mathrm{K}^{+}$ & c.a. 0.25 \\
\hline
\end{tabular}

Adapted from [43]

the degradation problems related to morphology and shape changes taking place during electric charging and discharge that are typical of secondary batteries. This type of $\mathrm{Zn}$-air battery concept has been chiefly studied by Electric Fuel Ltd. for defense applications, consumer electronic products and electric vehicles (buses in particular). In particular, the best-documented mechanically rechargeable zinc-air battery module employed is the one tested in electric buses, exhibiting a high specific energy density $(>200 \mathrm{Wh} / \mathrm{kg}$ ), able to power the vehicle for c.a. $400 \mathrm{~km}$ [91-94]. A typical regeneration route, schematically illustrated in Fig. 9, is described in [93] and includes the following operations: (i) disassembly, in which separator bags are removed from the anodes, and the zinc oxide discharge product (along with residual, undischarged zinc) is removed from the current collector frames; (ii) dissolution, in which zinc oxide is dissolved in a $\mathrm{KOH}$ solution to form a zincate-rich feed, according to the following reaction: $\mathrm{ZnO}+2 \mathrm{KOH}+\mathrm{H}_{2} \mathrm{O} \rightarrow \mathrm{K}_{2} \mathrm{Zn}(\mathrm{OH})_{4}$; (iii) electrowinning, in which the zincate solution is electrolyzed according to the following reaction: $\mathrm{K}_{2} \mathrm{Zn}(\mathrm{OH})_{4} \rightarrow \mathrm{Zn}+2 \mathrm{KOH}+\mathrm{H}_{2} \mathrm{O}+1 / 2 \mathrm{O}_{2}$; (iv) reassembly, in which the electrowon zinc, together with residual (charged) metallic zinc, is compacted onto the current collector frame and the anode is inserted into a separated bag.

\section{Electrically rechargeable $\mathbf{Z n - a i r}$ batteries}

In this section, a discussion of the anode, cathode and electrolyte materials employed in electrically rechargeable $\mathrm{Zn}$-air batteries (ERZAB) will be provided. In addition, the main problems, limiting their commercialization and widespread application, will be discussed. It is worth underlining that most of the materials employed in primary $\mathrm{Zn}$-air batteries are also used in ERZAB, especially the anode materials, the electrolyte and the catalysts for the oxygen reduction reaction (ORR). Of course, the main research challenges and difficulties in materials selection stem from the requirement of reversibility and efficiency in 


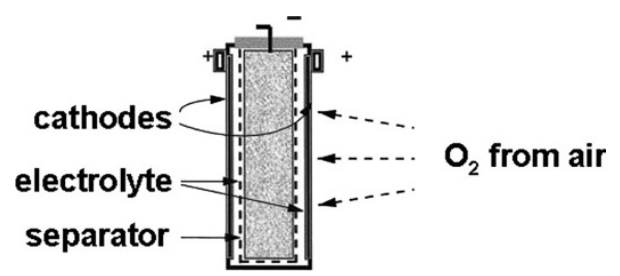

Fig. 8 Schematic diagram of a mechanically rechargeable zinc-air battery (Electric Fuel company). Reproduced with permission from [93]

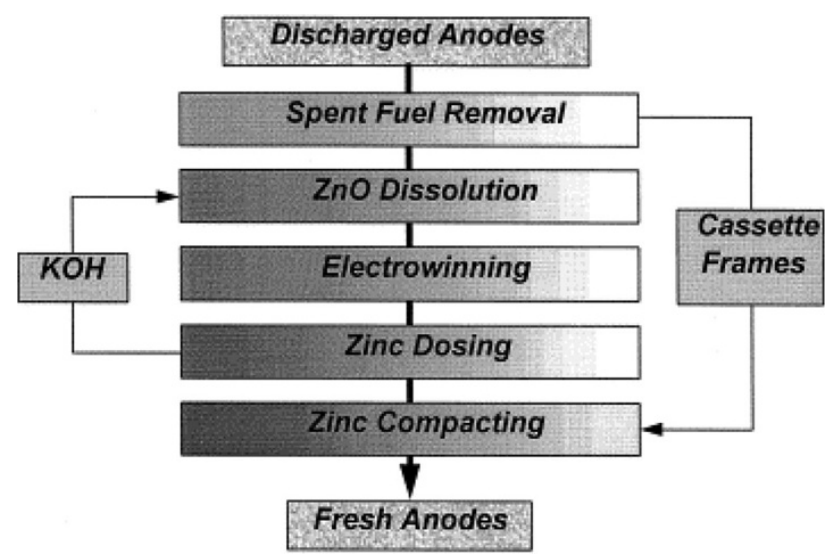

Fig. 9 Regeneration process of zinc anodes. Reproduced with permission from [93]

both discharge and charge processes. Li et al. [69], in a very recent paper (May 2013) demonstrated an excellent bifunctional electrocatalyst, exhibiting optimal ORR and OER activities during discharge and charging processes, respectively.

Anode materials

As in the primary $\mathrm{Zn}$-air battery, in the electrically rechargeable one, the anode material is zinc. However, in a secondary battery, this component changes structure and shape during repeated charge/discharge cycles, corresponding to zinc dissolution and re-deposition for several reasons, chiefly inhomogeneous current distribution and presence of concentration gradients in the electrolyte. As far as the shape changes are concerned, the typical shape change problems that have been reported to take place during charging are dendrite formation (leads to the loss of active material and to short-circuiting) and electrode densification (causing the originally porous zinc to leave active locations and agglomerate into self-screening compacts) [42]. It is worth noting that the different types of shape change phenomena can be strongly interconnected. A comprehensive account of shape change phenomena can be found in Ref. [43]. In the quest for reversible electrical recharging processes, effective dendrite suppression was achieved by applying a zeolite film over the zinc electrode [94]. This film keeps the $\mathrm{Zn}^{2+}$ discharge product close to the electrode, preventing it from being flushed away into the electrolyte.

\section{Cathode materials}

As hinted at above, at the cathode of a rechargeable $\mathrm{Zn}$-air battery, both the oxygen reduction reaction (ORR) and the oxygen evolution reaction (OER) are key factors for the efficiency of the system. Presently, a cathode material that is efficient and durable for both ORR and OER is not available, but research in the field seems active. Reference [42] reports on a novel core-corona bifunctional catalyst (CCBC) consisting of lanthanum nickelate centers supporting nitrogen-doped carbon nanotubes (NCNT). Reference [95] reports on the preparation of $\mathrm{MnO}_{2}$ nanotubes functionalized with $\mathrm{Co}_{3} \mathrm{O}_{4}$ nanoparticles for bifunctional air cathodes. These hybrid $\mathrm{MnO}_{2} / \mathrm{Co}_{3} \mathrm{O}_{4}$ nanomaterials exhibit enhanced catalytic reactivity toward oxygen evolution reaction under alkaline conditions compared with $\mathrm{MnO}_{2}$ nanotubes or $\mathrm{Co}_{3} \mathrm{O}_{4}$ nanoparticles alone. Reference [96] reports on novel silver nanoparticles-decorated $\mathrm{MnO}_{2}$ nanorods as an air electrode bifunctional catalyst. An alternative to the use of bifunctional catalysts is the approach of employing two specialized air cathodes for ORR and OER, respectively [69].

\section{Electrolyte}

The electrolyte most commonly employed in an electrically rechargeable $\mathrm{Zn}$-air battery is again $\mathrm{KOH}$. However, in the oxidation-reduction cycling, the electrochemistry of zinc in potassium hydroxide gives some problems because the precipitation of zinc oxide is irreversible and reduces the availability of $\mathrm{Zn}^{2+}$ ions upon cycling. The use of chelating ionic liquids has been proposed to circumvent precipitation issues [97].

\section{Mathematical modeling of electrically rechargeable} Zn-air batteries

To the best of our knowledge, just one paper has appeared on the mathematical modeling of the thickness of the anode and the optimal $\mathrm{KOH}$ concentration. Reference [98] presents a numerical model for a single-cell rechargeable $\mathrm{Zn}$-air batteries able to estimate the $\mathrm{I}-\mathrm{V}$ response of the cell, the individual $\mathrm{Zn}$ and $\mathrm{O}_{2}$ electrode potentials as well as the potential and concentration profiles (see Fig. 10). The model proposed in [98] consists of two partial differential equations for the material balance of ions moving in the electrolyte and solid species locked in the anode. 


\section{Zinc-air fuel cell}

Zinc-air fuel cell systems are potentially attractive for stationary and large-scale production and storage of electric energy. At variance with primary and electrically rechargeable zinc-air batteries, the zinc-air fuel cells (ZAFCs) are based on the flow of a mixture of $\mathrm{Zn}$ particles and electrolyte. $\mathrm{Zn}$ particles produced by different methods have been tested, including cut wire chunks, compacted electrodeposited dendrites, $\mathrm{Zn}$ spheroids reconstructed electrochemically in a spouted bed reactor (see, e.g., Fig. 11); zinc pellets are preferred to compacted dendrites owing to their better fluid dynamic behavior [93, 99-102]. The spent $\mathrm{Zn}$ particles, along with the $\mathrm{KOH}$ electrolyte, are replaced hydraulically by pumping from an external tank. Moreover, during discharge potassium zincate is continuously pumped away with the electrolyte. A schematic representation of a regenerative zinc-air fuel cell is shown in Fig. 12 [43].

\section{Conclusions}

In this review, the different types of zinc-air batteries described in the literature and their functional components are examined from the point of view of electrochemical

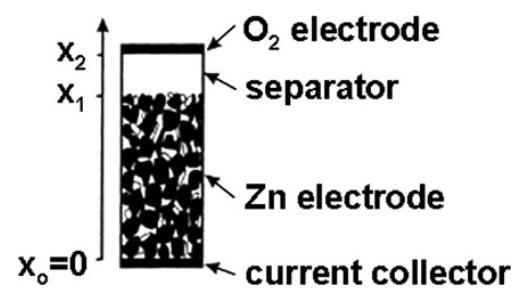

Fig. 10 Model of the one-dimension single-cell $\mathrm{Zn}$-air battery. Reproduced with permission from [98] materials science. Among all metal-air batteries, the zincair ones are of particular interest since in principle they can be safer, cheaper and more environmentally friendly than other competing technologies. Furthermore, zinc-air batteries, both primary and electrically rechargeable, can meet the requirements of the whole range of applications: portable electronics, medium-scale energy production and storage and eventually grid storage. Fully engineered secondary zinc-air batteries are not yet available: research and development is still needed, especially in the fields of: (i) shape changes of the $\mathrm{Zn}$ electrode during charge/discharge cycles, (ii) durable and dual air cathode catalysts, (iii) $\mathrm{KOH}-$ based electrolyte chemistry. As far as highpower applications are concerned, the mechanically rechargeable and the flowing anode concepts are particularly appealing for the possibility of achieving essentially continuous operation as well as of implementing an off-line electrical generation process.

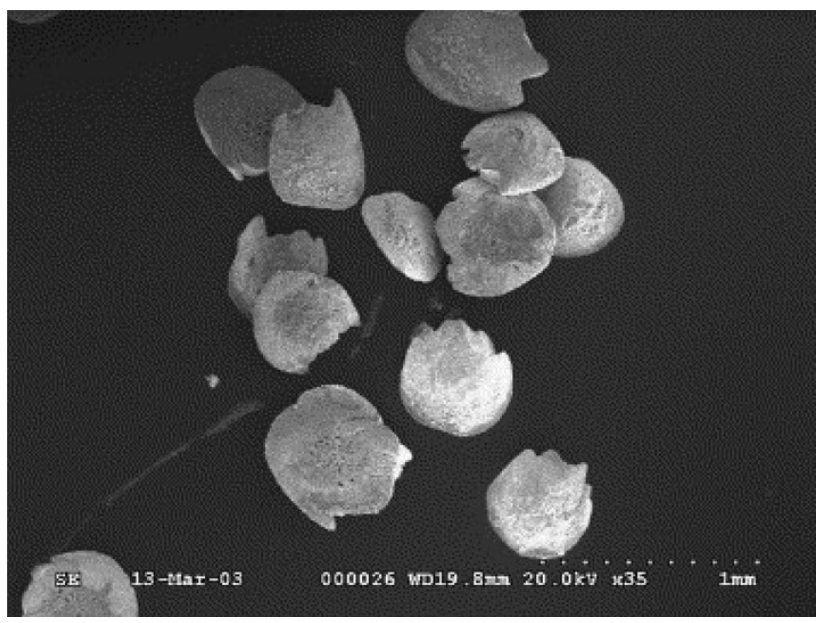

Fig. 11 SEM image of the zinc pellets obtained after regeneration. Reproduced with permission from [99]
Fig. 12 Schematic illustration of the flow of material in a zincair fuel cell system. Reproduced with permission from [43]

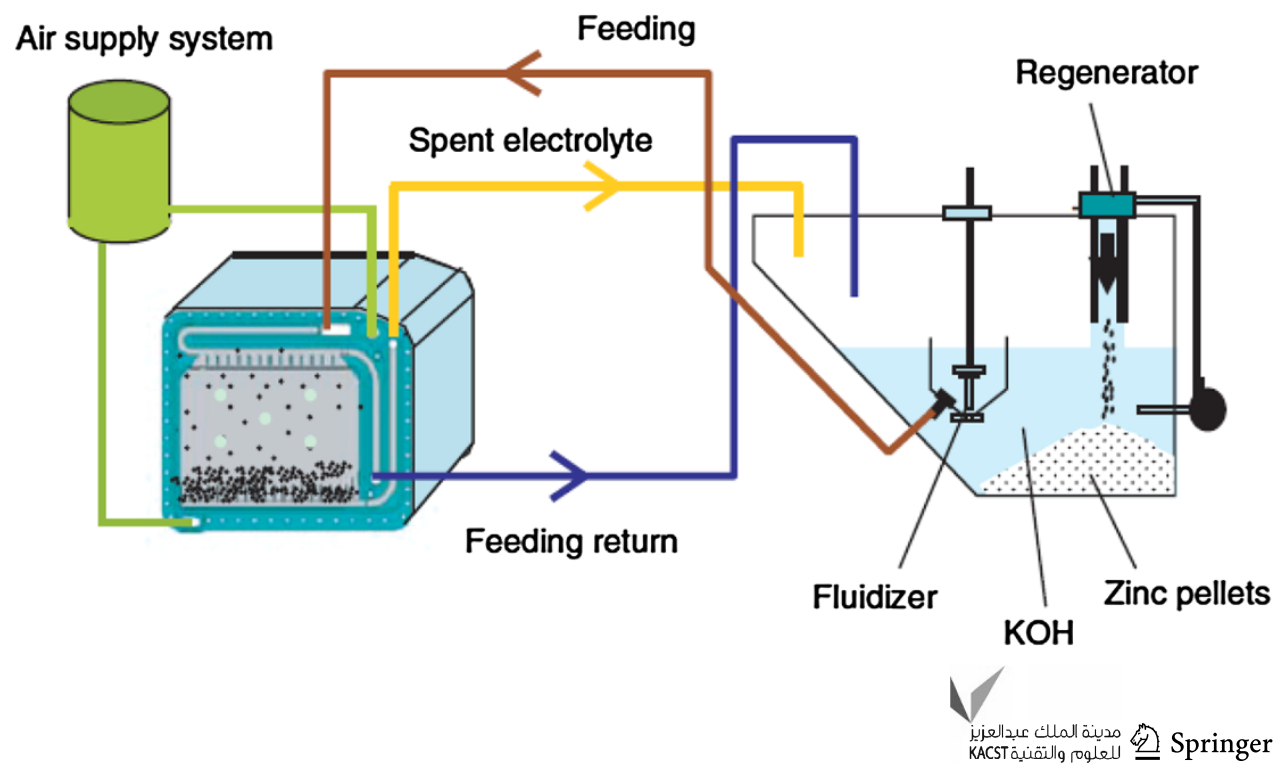


Open Access This article is distributed under the terms of the Creative Commons Attribution License which permits any use, distribution, and reproduction in any medium, provided the original author(s) and the source are credited.

\section{References}

1. Omer, A.M.: Energy, environment and sustainable development. Renew. Sustain. Energy Rev. 12, 2265-2300 (2008)

2. Bose, B.K.: Global energy scenario and impact of power electronics in 21st century. IEEE Trans. Ind. Electron. 60, 2638-2651 (2013)

3. Omer, A.M.: Green energies and the environment. Renew. Sustain. Energy Rev. 12, 1789-1821 (2008)

4. Solangi, K.H., Islam, M.R., Saidur, R., Rahim, N.A., Fayaz, H.: A review on global solar energy policy. Renew. Sustain. Energy Rev. 15, 2149-2163 (2011)

5. Islam, M.R., Mekhilef, S., Saidur, R.: Progress and recent trends of wind energy technology. Renew. Sustain. Energy Rev. 21, 456-468 (2013)

6. Devabhaktuni, V., Alam, M., Shekara Sreenadh Reddy Depuru, S., Green Ii, R.C., Nims, D., Near, C.: Solar energy: trends and enabling technologies. Renew. Sustain. Energy Rev. 19, 555-564 (2013)

7. Tie, S.F., Tan, C.W.: A review of energy sources and energy management system in electric vehicles. Renew. Sustain. Energy Rev. 20, 82-102 (2013)

8. Pollet, B.G., Staffell, I., Shang, J.L.: Current status of hybrid, battery and fuel cell electric vehicles: from electrochemistry to market prospects. Electrochim. Acta 84, 235-249 (2012)

9. Dunn, B., Kamath, H., Tarascon, J.-M.: Electrical energy storage for the grid: a battery of choices. Science 334, 928-935 (2011)

10. http://www.energy.gov/sites/prod/files/2013/12/f5/Grid\%20Energy \%20Storage\%20December\%202013.pdf. Accessed Feb 2014

11. Koohi-Kamali, S., Tyagi, V.V., Rahim, N.A., Panwar, N.L., Mokhlis, H.: Emergence of energy storage technologies as the solution for reliable operation of smart power systems: a review. Renew. Sustain. Energy Rev. 25, 135-165 (2013)

12. Rastler, D.: Electricity energy storage technology options: a white paper primer on applications, costs and benefits, p. 1020676. EPRI, Palo Alto (2010)

13. Steinke, F., Wolfrum, P., Hoffmann, C.: Grid vs. storage in a 100\% renewable Europe. Renew. Energy 50, 826-832 (2013)

14. http://www.sbc.slb.com/SBCInstitute/Publications/Electricity Storage.aspx. Accessed Feb 2014

15. Yang, Z., Zhang, J., Kintner-Meyer, M.C.W., Lu, X., Choi, D., Lemmon, J.P., Liu, J.: Electrochemical energy storage for green grid. Chem. Rev. 111, 3577-3613 (2011)

16. Alotto, P., Guarnieri, M., Moro, F.: Redox flow batteries for the storage of renewable energy: a review. Renew. Sustain. Energy Rev. 29, 325-335 (2014)

17. Ding, C., Zhang, H., Li, X., Liu, T., Xing, F.: Vanadium flow battery for energy storage: prospects and challenges. J. Phys. Chem. Lett. 4, 1281-1294 (2013)

18. Leung, P., Li, X., Ponce de Leon, C., Berlouis, L., Low, C.T.J., Walsh, F.C.: Progress in redox flow batteries, remaining challenges and their applications in energy storage. RSC Adv. 2, 10125-10156 (2012)

19. Leadbetter, J., Swan, L.G.: Selection of battery technology to support grid-integrated renewable electricity. J. Power Sources 216, 376-386 (2012)
20. http://www.technologyreview.com/news/512206/years-in-themaking-promising-rechargeable-metal-air-batteries-head-to-market/ . Accessed Feb 2014

21. http://www.eosenergystorage.com/zinc-air-batteries-for-grids/. Accessed Feb 2014

22. http://www.renault-ze.com. Accessed Nov 2013

23. http://www.bmw.com/com/en/newvehicles/1series/activee/2011/ showroom/index.html. Accessed Nov 2013

24. http://www.ford.com/cars/focus/trim/electric/. Accessed Nov 2013

25. http://tools.mercedes-benz.co.uk/current/smart/brochures/smartelectric-drive.pdf. Accessed Nov 2013

26. http://www.mitsubishi-motors.com/special/ev/whatis/index.html. Accessed Nov 2013

27. http://www.nissan.co.uk/vehicles/electric-vehicles/electric-leaf/ leaf.htm\#vehicles/electric-vehicles/electric-leaf/leaf. Accessed Nov 2013

28. http://www.teslamotors.com/models. Accessed Nov 2013

29. http://www.toyota.com/rav4ev/. Accessed Nov 2013

30. http://emobility.volkswagen.it/it/it/private/technology.html. Accessed Nov 2013

31. http://www.opel.com/microsite/ampera/\#/ampera_charging_daily_ use. Accessed Nov 2013

32. http://social.ford.com/our-articles/cuvs/c-max/latest-ford-c-maxnews-from-the-2011-north-american-international-auto-show/. Accessed Nov 2013

33. Cheng, F., Chen, J.: Metal-air batteries: from oxygen reduction electrochemistry to cathode catalysts. Chem. Soc. Rev. 41, 2172-2192 (2012)

34. Catenacci, M., Verdolini, E., Bosetti, V., Fiorese, G.: Going electric: expert survey on the future of battery technologies for electric vehicles. Energy Policy. 61, 403-413 (2013)

35. Wang, J., Li, Y., Sun, X.: Challenges and opportunities of nanostructured materials for aprotic rechargeable lithium-air batteries. Nano Energy 2, 443-467 (2013)

36. Girishkumar, G., McCloskey, B., Luntz, A.C., Swanson, S., Wilcke, W.: Lithium-air battery: promise and challenges. J. Phys. Chem. Lett. 1, 2193-2203 (2010)

37. Rahman, M.A., Wang, X., Wen, C.: High energy density metalair batteries: a review. J. Electrochem. Soc. 160, A1759-A1771 (2013)

38. Lee, J.-S., Tai Kim, S., Cao, R., Choi, N.-S., Liu, M., Lee, K.T., Cho, J.: Metal-air batteries with high energy density: Li-air versus Zn-air. Adv. Energy Mater. 1, 34-50 (2011)

39. http://www.zinc.org/. Accessed Nov 2013

40. http://www.ilzsg.org/static/statistics.aspx. Accessed Nov 2013

41. Hamlen, R.P., Atwater, T.B.: Metal/air batteries, chapter 38. In: Linden, D., Reddy, T.B. (eds.) Handbook of batteries, 3rd edn. McGraw-Hill, New York (2002)

42. Chen, Z., Yu, A., Higgins, D., Li, H., Wang, H., Chen, Z.: Highly active and durable core-corona structured bifunctional catalyst for rechargeable metal-air battery application. Nano Lett. 12, 1946-1952 (2012)

43. Zhang, X.G.: Secondary batteries-zinc systemslzinc electrodes: overview. In: Jürgen, G. (ed.) Encyclopedia of electrochemical power sources, pp. 454-468. Elsevier, Amsterdam (2009)

44. http://commons.wikimedia.org/wiki/File:Zn-pourbaix-diagram.svg. Accessed Nov 2013

45. Thomas, S., Birbilis, N., Venkatraman, M.S., Cole, I.S.: Selfrepairing oxides to protect zinc: review, discussion and prospects. Corros. Sci. 69, 11-22 (2013)

46. Yang, C.-C., Lin, S.-J.: Improvement of high-rate capability of alkaline $\mathrm{Zn}-\mathrm{MnO}_{2}$ battery. J. Power Sources 112, 174-183 (2002) 
47. Zhang, X.G.: Fibrous zinc anodes for high power batteries. J. Power Sources 163, 591-597 (2006)

48. Othman, R., Basirun, W.J., Yahaya, A.H., Arof, A.K.: Hydroponics gel as a new electrolyte gelling agent for alkaline zinc-air cells. J. Power Sources 103, 34-41 (2001)

49. Mohamad, A.A.: $\mathrm{Zn} /$ gelled $6 \mathrm{M} \mathrm{KOH} / \mathrm{O}_{2}$ zinc-air battery. J. Power Sources 159, 752-757 (2006)

50. Lee, C.W., Eom, S.W., Sathiyanarayanan, K., Yun, M.S.: Preliminary comparative studies of zinc and zinc oxide electrodes on corrosion reaction and reversible reaction for zinc/air fuel cells. Electrochim. Acta 52, 1588-1591 (2006)

51. Müller, S., Holzer, F., Haas, O.: Optimized zinc electrode for the rechargeable zinc-air battery. J. Appl. Electrochem. 28, 895-898 (1998)

52. Masri, M.N., Mohamad, A.A.: Effect of adding potassium hydroxide to an agar binder for use as the anode in $\mathrm{Zn}$-air batteries. Corros. Sci. 51, 3025-3029 (2009)

53. Wu, G.M., Lin, S.J., Yang, C.C.: Alkaline Zn-air and Al-air cells based on novel solid PVA/PAA polymer electrolyte membranes. J. Membr. Sci. 280, 802-808 (2006)

54. Masri, M.N., Nazeri, M.F.M., Ng, C.Y., Mohamad, A.A.: Tapioca binder for porous zinc anodes electrode in zinc-air batteries. J. King Saud Univ. Eng. Sci. 2013. doi:10.1016/j.jksues. 2013.06.001

55. Devyatkina, T.I., Gun'ko, Y.L., Mikhalenko, M.G.: Development of ways to diminish corrosion of zinc electrode. Russ. J. Appl. Chem. 74, 1122-1125 (2001)

56. Zhang, C., Wang, J.M., Zhang, L., Zhang, J.Q., Cao, C.N.: Study of the performance of secondary alkaline pasted zinc electrodes. J. Appl. Electrochem. 31, 1049-1054 (2001)

57. Lan, C.J., Chin, T.S., Lin, P.H., Perng, T.P.: Zn-Al alloy as a new anode-metal of a zinc-air battery. J. New Mater. Electrochem. Syst. 9, 27-32 (2006)

58. El-Sayed, A.-R., Mohran, H., Abd El-Lateef, H.: Corrosion study of zinc, nickel, and zinc-nickel alloys in alkaline solutions by Tafel plot and impedance techniques. Metall. Mater. Trans. A 43, 619-632 (2012)

59. Lee, S.-M., Kim, Y.-J., Eom, S.-W., Choi, N.-S., Kim, K.-W., Cho, S.-B.: Improvement in self-discharge of $\mathrm{Zn}$ anode by applying surface modification for $\mathrm{Zn}$-air batteries with high energy density. J. Power Sources 227, 177-184 (2013)

60. Kim, K., Cho, Y.-H., Eom, S.W., Kim, H.-S., Yeum, J.H.: Anions of organic acids as gas suppressants in zinc-air batteries. Mater. Res. Bull. 45, 262-264 (2010)

61. Auinat, M., Ein-Eli, Y.: Enhanced inhibition of zinc corrosion in alkaline solutions containing carboxylic acid modified PEG. J. Electrochem. Soc. 152, A1158-A1164 (2005)

62. Ein-Eli, Y., Auinat, M., Starosvetsky, D.: Electrochemical and surface studies of zinc in alkaline solutions containing organic corrosion inhibitors. J. Power Sources 114, 330-337 (2003)

63. Kinoshita, K.: Electrochemical Oxygen Technology. Wiley, New York (1992)

64. Harting, K., Kunz, U., Turek, T.: Zinc-air batteries: prospects and challenges for future improvement. Z. Phys. Chem. 226, 151-166 (2012)

65. Cao, R., Lee, J.-S., Liu, M., Cho, J.: Recent progress in nonprecious catalysts for metal-air batteries. Adv. Energy Mater. 2, 816-829 (2012)

66. Neburchilov, V., Wang, H., Martin, J.J., Qu, W.: A review on air cathodes for zinc-air fuel cells. J. Power Sources 195, 1271-1291 (2010)

67. Chen, Z., Choi, J.-Y., Wang, H., Li, H., Chen, Z.: Highly durable and active non-precious air cathode catalyst for zinc air battery. J. Power Sources 196, 3673-3677 (2011)

68. Lee, J.-S., Lee, T., Song, H.-K., Cho, J., Kim, B.-S.: Ionic liquid modified graphene nanosheets anchoring manganese oxide nanoparticles as efficient electrocatalysts for $\mathrm{Zn}$-air batteries. Energy Environ. Sci. 4, 4148-4154 (2011)

69. Li, Y., Gong, M., Liang, Y., Feng, J., Kim, J.-E., Wang, H., Hong, G., Zhang, B., Dai, H.: Advanced zinc-air batteries based on high-performance hybrid electrocatalysts. Nat. Commun. 4 (2013). doi:10.1038/ncomms2812

70. Liu, X.-Y., Xu, X.-Z.: Mesoscopic numerical computation model of air-diffusion electrode of metal/air batteries. Appl. Math. Mech. 34, 571-576 (2013)

71. Deborski, G.A.: US Patent 4,256,545 (1978)

72. Armstrong, W.A.: US Patent 3,948,684 (1976)

73. Passaniti, J., Dopp, R.B.: US Patent 5,378,562 (1995)

74. Passaniti, J.L., Dopp, R.B.: US Patent 5,308,711 (1994)

75. Bach, S., Baffier, N., Henry, M., Livage, J.: FR Patent 2,659,075 (1991)

76. Hoge, W.H.: US Patent 4,906,535 (1988)

77. Hoge, W.H.: US Patent 5,032,473 (1991)

78. Dopp, R.B.: US Patent 5,656,395 (1997)

79. Golovin, N.: US Patent 6,444,609 (2002)

80. Golovin, N.: US Patent 6,428,931 (2002)

81. Ndzebet, R.: US Patent 6,780,347 (2002)

82. Koshiba, N., Hayakawa, H., Momose, K., Ohta, A.: US Patent 4,595,643 (1984)

83. Sassa, R.L., Zuckerbrod, D., Buerger, W., Bacino, J.E.: US Patent 6,921,606 (2005)

84. Sun, F., Wang, F.: US Patent 6,248,476 (2001)

85. Borbelly, L., Wang, F.: US Patent 6,248,476 (1990)

86. McEvoy, J.J.: US Patent 4,585,710 (1986)

87. Kelsey, G.S., Chalilpoyil, P., Trainer, P.D., Kaplan, A., Cintra, G., Vu, V.H., Sillesky, J.D.: US Patent 6,207,322 (1998)

88. Shun, Y-K., Lou, C-L.: US Patent 6,127,061 (2000)

89. Blanchart, A.P.O., Van Der Poorten, C.J. E.: US Patent 4,696,872 (1987)

90. Henry, G.: US Patent 4,333,993 (1982)

91. http://www.electric-fuel.com/index.html. Accessed Nov 2013

92. Koretz, B., Goldstein, J.R.: Regeneration of zinc anodes for the electric fuel(R) zinc-air refuelable EV battery system. In: Energy Conversion Engineering Conference. IECEC-97., Proceedings of the 32nd Intersociety, vol. 2, pp. 877-882 (1997)

93. Goldstein, J., Brown, I., Koretz, B.: New developments in the Electric Fuel Ltd. zinc/air system. J. Power Sources 80, 171-179 (1999)

94. Bergman, M.: Synthesis, preparation and characterization of materials for metal air battery applications. Master of Science Thesis in Applied Physics, Department of Applied PhysicsDivision of Condensed Matter Physics. Chalmers University of Technology (2013)

95. Du, G., Liu, X., Zong, Y., Hor, T.S.A., Yu, A., Liu, Z.: $\mathrm{Co}_{3} \mathrm{O}_{4}$ nanoparticle-modified $\mathrm{MnO}_{2}$ nanotube bifunctional oxygen cathode catalysts for rechargeable zinc-air batteries. Nanoscale 5, 4657-4661 (2013)

96. Goh, F.W.T., Liu, Z., Ge, X., Zong, Y., Du, G., Hor, T.S.A.: Ag nanoparticle-modified $\mathrm{MnO}_{2}$ nanorods catalyst for use as an air electrode in zinc-air battery. Electrochim. Acta 114, 598-604 (2013)

97. Kar, M., Winther-Jensen, B., Forsyth, M., MacFarlane, D.R.: Chelating ionic liquids for reversible zinc electrochemistry. Phys. Chem. Chem. Phys. 15, 7191-7197 (2013)

98. Deiss, E., Holzer, F., Haas, O.: Modeling of an electrically rechargeable alkaline $\mathrm{Zn}$-air battery. Electrochim. Acta 47, 3995-4010 (2002)

99. Smedley, S.I., Zhang, X.G.: A regenerative zinc-air fuel cell. J. Power Sources 165, 897-904 (2007)

100. Smedley, S.I., de Tezanos Pinto, M., des Jardins, S.R., Novkov, D.J., Gulino, R.: Discrete particle electrolyzer cathode and 
method of making same. US Patent Application Publication No. 2004/0168922 A1, (September 2nd, 2004)

101. Sapkota, P., Kim, H.: Zinc-air fuel cell, a potential candidate for alternative energy. J. Ind. Eng. Chem. 15, 445-450 (2009)
102. Cooper, J.F., Krueger, R.: The refuelable zinc-air battery: alternative techniques for zinc and electrolyte regeneration. Final report UCRL-TR-218414, ILZRO Program ZB-1 Zinc-air batteries, (April 15th, 1996) 